Research Article

\title{
Renewable Energy Consumption, Trade Openness, and Environmental Degradation: A Panel Data Analysis of Developing and Developed Countries
}

\author{
Hayat Khan $\mathbb{D}^{\mathbb{D}},{ }^{1}$ Liu Weili $\mathbb{D}^{\mathbb{D}},{ }^{1}$ Itbar Khan $\mathbb{D}^{\mathrm{D}},{ }^{2}$ and Sikeo Khamphengxay $\mathbb{D}^{3}$ \\ ${ }^{1}$ China Center for Special Economic Zone Research, Shenzhen University, Shenzhen, China \\ ${ }^{2}$ Business School of Xiangtan University, Xiangtan, Hunan, China \\ ${ }^{3}$ Business School of Guangxi University, Guangxi, Nanning, China \\ Correspondence should be addressed to Liu Weili; liuweili83@yahoo.com
}

Received 15 December 2020; Revised 19 January 2021; Accepted 6 February 2021; Published 3 March 2021

Academic Editor: Jan Kazak

Copyright (c) 2021 Hayat Khan et al. This is an open access article distributed under the Creative Commons Attribution License, which permits unrestricted use, distribution, and reproduction in any medium, provided the original work is properly cited.

Studies regarding environmental degradation and its association with different factors have got considerable attention recently in the prevalent literature but with assorted outcomes which have been a guide to the ongoing debate on environmental studies. Energy from renewable sources has been considered beneficial for environmental quality while it is still below the anticipated level especially in developing economies. Openness to trade is important to enhance economic growth while it has been overawed to worsen the quality of environment due to deprived policies especially in developing countries. Subsequently, the present research investigates trade openness, renewable energy consumption, and foreign direct investment in carbon emission in the world developing and developed countries by employing static, dynamic and long run estimators. Trade openness has been found to have a decreasing effect on carbon emission in developed countries while degrading the quality of environment in developing countries while renewable energy consumption enhances environmental quality in both samples. The impact of tourism on carbon emission varies in different samples where FDI increases emission in developed countries while having a negative effect of carbon emission in developing countries. The long run estimators also evidence the existence of long run association among variables. The outcomes of this study have considerable policy implication regarding trade openness policy formulation to upsurge environmental quality especially in developing countries. The study has further suggestions regarding tourism and promoting the use of renewable energy sources by avoiding the use of former's energy to enhance environmental quality.

\section{Introduction}

The association of trade openness and carbon emission has been a major concern for the researchers and policy makers in the preceding literature. Free trade is likely to have negative or positive environmental effects due to different effects and composition. Trade openness has been focused in recent literature of environmental quality but different studies have got dissimilar conclusions. Some researchers argue that trade openness positively affects carbon emisison such as Ferrantino [1] and Antweiler, Copeland, and Taylor [2]. Trade openness is considered as a key economic growth determinant; however, openness through import and export activities causes pollution and deteriorates environmental quality in some countires. The quality of environment is deteriorating due to increase in trade openness, foreign direct investment, and financial globalization especially in developing countires due to poor policies as these countries are trying to increase economic growth through these factors. This debate regarding the impact of trade on environment is considered due to the increasing volume of trade activities among different countries and the changing in environmental quality. Energy consumption also performs an important role in enhancing economic growth as Ben [3] indicates that the economic growth has been affected positively by trade openness and energy consumption. Trade openness, foreign direct investment, and energy consumption from fossil fuels may increase carbon emission 
and negatively affect environmental quality especially in developing countries; however, the impact of renewable energy on carbon emissions has been documented in several studies. These studies have found that the use of renewable energy consumption reduces carbon emissions [4, 5]. Similarly, Khan et al. [6] and Khan et al. [7] argue that the use of renewable energy from renewable energy sources instead of energy consumption from fossil fuels enhances environmental quality and reduces carbon emission. The impact of tourism has also been investigated by several researchers as it plays a very important role in economic growth and affects environmental quality such as [8] who claim that increase in tourism activities brings increase in climate change and energy consumption. They further state that the impact of tourism on carbon emission and energy consumption is positive and significant. The impact of FDI on carbon emission has also been investigated by several researchers. Some studies indicate that foreign direct investment increases carbon emission while some argue that FDI lowers the level of carbon emission and some other studies indicate that the impact on FDI on environment tvaries in countries and regions. Some studies have found the negative impact of foreign direct investment on carbon emission such as Wang and Liu [9] and Huang et al. [10] while some researchers argue that the impact of foreign direct investment on carbon emission is positive (Zhu et al., [11]). On the other hand, António Cardoso Marques and Rafaela Caetano [12] state that FDI decreases emissions in high-income countries, while increasing them in the short run in middle-income countries. Considering other factors, this study investigates the impact of renewable energy consumption, trade openness, foreign direct investment, and tourism on environmental quality in developed and developing countries of the world for the period of 1985 to 2018. We have selected the sample of developing and developed countries to find the impact of different factors on environmental quality which might help give a clear picture of differences between the two samples of developing and developed countries policies regarding trade openness, foreign direct investment, and the development of renewable energy sources and draw a meaningful conclusion. To the best of our knowledge, we consider this study to be the first to discuss the degree of trade openness and the impact of renewable energy consumption on carbon emission as most previous studies have mentioned that trade openness is harmful to environmental quality. We pointed out in this study that the impact of trade openness between countries on the environment is different and national or regional emissions will also discuss carbon emissions or environmental degradation. Trade openness is important for economic growth and we are exploring that whether trade is harmful for environmental quality in our sample countries or not while making polices for trade to enhance economic growth through FDI. Our study expects that the impact of trade openness on environmental quality is not the same for every country or sample but it varies on region and countries due to trade policies. We also expect that the use of renewable energy consumption from renewable sources instead of using traditional energy from fossil fuels is beneficial for environmental quality of a country. The rest of this paper is structured as follows. Section 2 presents empirical literature, Section 3 illustrates the study models and methods, and Section 4 is composed of the findings discussions while Section 5 presents the study conclusion.

\section{Literature Review}

There have been conducted numerous studies on carbon emission and its different determinants such as trade, energy consumption, and FDI $[5,13,15]$. Trade openness plays a very significant role in enhancing economic growth while it is also causing environmental issues such as increase in carbon emission. Energy consumption also increases economic growth while it influences environmental quality and the use of renewable energy from renewable sources has been considered beneficial for the quality of environment. There is also different opinion of researchers that FDI positively affects carbon emission while some argue that it is reducing carbon emission. Similarly, the impact of tourism activities on environmental quality has also been studied by several researchers but has got mixed results. Consequently, a step-by-step literature review is given on trade openness, carbon emission, energy consumption, and carbon emission as follows.

2.1. Trade Openness and Carbon Emission. The association of trade openness and carbon emission has been debated for a long time and it is an important issue in trade policies. Several researchers have studied the impact of trade openness and its impact on environmental quality but they have found mixed results. Some researchers in the proceeding literature argue that trade openness is harmful for environmental quality where some have stated that trade openness is good for the quality of environment and some others have found even no association between the two. For instance, Bernard and Mandal [16] have conducted a study on the trade environment relationship in 60 developing and emerging countries for the period of 2002 to 2012. They have employed fixed effect and GMM model and found that trade openness improves environmental performance index. Their results of GMM model indicate that political factors enhance environmental quality while population and income have detrimental effects. Similarly, Ling et al. [17] have studied the impact of trade openness on environmental degradation in five Asian countries for the period of 1995 to 2014 . They have found long run association between the variables for their sample countries. They further confirm the bidirectional causal relationship between carbon emission, energy consumption, and economic growth in short run. Likewise, Gasimli, Gamage, Shihadeh, Rajapakshe, and Shafiq [18] studied the association between trade, energy, urbanization, and environmental degradation where the findings of their study indicate that there exists a long-term association between these variables. They further stipulate that energy consumption will cause short-term and long-term carbon 
emissions. Mahrinasari et al. [19] explored the link between environmental degradation and trade openness in Asian countries. Their results indicate a positive correlation between carbon emissions and trade liberalization. Similarly, Le et al. [20] have examined the trade environment relationship in a panel of cross countries by employing panel cointegration approach. Their findings show the long run association between trade openness, carbon emission, and economic growth. They further show that an increase in trade openness leads to environmental degradation; however, the effect differs in different sample of countries. They also found harmful effect of trade on environment in low- and middleincome economies. Another study was conducted by Q. Zhang et al. [21] on the relationship between trade openness and carbon emission in ten newly industrialized countries for the period of 1971 to 2013. Their findings indicate negative impact of trade openness on carbon emission; however, they have found that energy and real GDP exert a positive effect on carbon emission. Moreover, [22] argue that their study variables were cointegrated for some countries and trade openness, energy consumption, and real income are the main drivers of carbon emission in their sample countries in the long run. Njindan Iyke and Ho [23] have found that high level of trade openness is related to low emission in the long run while high openness is associated with high carbon emission in short run. On the other hand, the study of Fang, Huang, and Yang [24] found that increase in economic growth brings increase in waste water pollution which varies on the specific level of trade openness. Omri [25] states that the impact of trade openness on environment is unimportant and inverse. Authors in [19] explored the linkage of environmental degradation and trade in Asian countries where their results illustrate that carbon emission and trade liberalization have positive association. Some other studies indicate the negative impact of trade openness on carbon emission where Yu, Nataliia, Yoo, and Hwang [26] have found the impact of trade openness on environmental quality in CIS counties for the period of 2000 to 2013. Their findings show that trade openness increases emission directly while there is decreasing effect indirectly which is the reason of negative effect on per capita income. Lastly, Sun, Tariq, Haris, and Mohsin [27] studied the relationship between trade openness and emission in belt and road countries for the time period of 1991 to 2014. Their findings indicate that their study variables are stationary in the long run and trade openness exerts positive and negative impact on environment and these effects vary on different income groups of the sample countries.

2.2. Energy Consumption and Carbon Emission. The preceding literature also shows the relationship of energy consumption, renewable energy consumption, and carbon emission. For instance, [28] have explored the determinants of carbon emission in developing countries where their results illustrate that economic growth and energy consumption are affecting carbon emission positively in South East Asia. They further state that carbon emission is higher in Indonesia and Vietnam than other countries in the region. Osobajo et al. [29] have investigated the impact of energy consumption and economic growth on carbon emission by using OLS, fixed effect, granger causality, and panel cointegration tests for seventy countries for the period of 1994-2013. They have found bidirectional causal relationship of variables with carbon emission and unidirectional relationship with energy consumption. They have also found long run association among energy consumption, economic growth, and carbon emission. The author in [30] has determined the link between economic growth and renewable energy consumption. His results show that the increase in production has promoted the use of renewable energy. Similarly, [31] studied renewable energy consumption and economic growth. Their findings indicate that there is a negative correlation between these two variables. In addition, [32] found a long-term relationship between economic growth, carbon emission, and renewable energy consumption. Khan et al. [7] have studied renewable energy consumption and carbon emission in the global panel. Their findings show the negative impact of renewable energy on carbon emission while they have found positive impact of financial development on carbon emission. J.-M. Lee et al. [33] have also explored the relationship of carbon emission and financial development and energy consumption for the period of 1971-2007 in 25 countries of OECD. They have used FMOLS model and cross-sectional dependence model where they show that there is no support of EKC curve existence in the sample countries. They further state that the impact of financial development on carbon emission is negative only for eight countries. Some studies have examined financial development and carbon emission with other factors such as Odugbesan and Rjoub $[34,35]$ who have found that energy and growth hypothesis were unidirectional from energy consumption in Nigeria and Indonesia where the whole sample results indicate that there exists long run association of the study variables. Similarly, Siddique [36] has explored the relationship of trade, financial development, energy consumption, and carbon emission in Pakistan for the period of 1980 to 2015 by using ADF and ARDL methods for analysis. The long run association among the variables has been found in his study for Pakistan. More recently, $\mathrm{Ma}$ and $\mathrm{Fu}$ [37] have studied the impact of financial development on energy consumption in 120 countries by using GMM model. They found that overall system of financial development positively and significantly affects energy consumption in the sample. They further show that financial development positively affects energy consumption in developing countries while no evidence has been found for developed countries. Jian, Fan, He, Xiong, and Shen [38] found that unidirectional granger causality forms energy consumption to financial development. They also show that financial development and energy consumption positively affect carbon emission. Likewise, a recent paper published by Jiang and $\mathrm{Ma}$ [39] has examined the impact of financial development on carbon emission in the globe. They found that financial development increases carbon emission in the globe while they did not find solid result for developing and emerging 
economies. They state that financial development is insignificant for carbon emission in developed counties.

2.3. Foreign Direct Investment and Carbon Emission. It has been also argued by several researchers in the preceding literature that foreign direct investment and carbon emission have association where some state the negative impact of FDI on carbon emission and some indicate the positive impact of FDI on carbon emission. Adamu and Shafiq [40] analyzed the impact of foreign direct investment, energy, and export varieties on environmental degradation and found long-term links between variables. Their results show that the variables are positively correlated with environmental degradation in India, but there is no EKC hypothesis existing for India. Environmental degradation has a one-way causal relationship with income and trade. In the long run, there is a two-way causal relationship between environmental degradation and energy consumption, export varieties, and environmental degradation. Likewise, L. Zhu et al. [41] have found that foreign direct investment increases carbon emission in the sample cities of China. They further state that FDI reduces urban emission during lagging period of one phase. A study conducted by Li et al. [42] examines the foreign direct investment relationship with environment by using oriented quantile regression model where they indicate that there exists a negative relationship between the study variables. In addition, $\mathrm{Li}$ et al. [42] studied the impact of FDI on environmental performance and found a negative correlation between FDI and environmental performance. They used directed quantile regression and their findings indicate a negative correlation between the two variables. Authors in [43] explored the problem of foreign direct investment causing the deterioration of the Asian environment. They further stipulated that the environment has always been affected by foreign direct investment. Authors in [9] proposed the fact that foreign direct investment has affected China's economic growth and had a controversial impact on the environment. Similarly, [44] believe that there is a cointegration relationship between foreign direct investment, energy consumption, carbon emission, and economic growth. Huynh and Hoang [45] have studied the impact of FDI on air pollution by considering the quality of institutions in a sample of 19 developing countries of Asia for the time period of 2002 to 2015 . They have found that the inflow of FDI in initial stage increases pollution and the improvement in institutional quality lowers this effect till the achievement of a threshold of institutions quality. However, beyond the threshold, FDI has been found to lower the air pollution in the Asian developing countries. Similarly, the study of Zhu et al. [46] shows the negative impact of FDI on carbon emission and they have found the increasing impact of energy consumption on carbon emission.

2.4. Carbon Emission, Tourism, and Economic Growth. A large number of studies have been conducted on the association of carbon emission and tourism where [47] have conducted a study on the relationship of tourism, economic growth, and carbon emission in China. They found that energy consumption and carbon emission have been persuading by tourism in China. They also state that tourism is the main source of emission in China. Similarly, [48] studied the link between tourism and carbon emission and they discovered the negative impact of carbon emission on the tourism industry of the sample countries. Zhang and Zhang [49] have studied tourism, energy consumption, and carbon emission in 30 provinces of China. They have found long run equilibrium relationship among the study variables. They have found bidirectional short-term causalities between GDP and tourism while there were unidirectional short run causalities running from energy consumption to their analyzed variables and bidirectional long run between carbon emission and economic growth, carbon emission and tourism, and GDP and tourism. Authors in [8] found that tourism has increased energy consumption and significantly generated environmental pollution from carbon dioxide emissions. [50] evidenced that there is long run causality between tourism and energy consumption in Malaysia. Fethi and Senyucel [51] have investigated the role of tourism development on carbon emission in 50 tourist destination countries. They have applied multiple models where their findings indicate that tourism development has a significant long-term effect on the extended version of EKC while carbon emission levels significantly fluctuate over years through tourism development. They also state that tourism development has a positive impact on carbon emission level in the case of some countries of their sample. Authors in [52] have studied carbon emission and tourism where they state that tourism lowers carbon emission in Thailand. Similarly, Abul, Satrovic, and Muslija [53] have examined the relationship between tourism and foreign direct investment for the period of 1995 to 2015 in 113 countries. They found that tourism has positive impact on foreign direct investment. Moreover, Zaman, Shahbaz, Loganathan, and Raza [54] have found causal evidence of tourism induced carbon emission and economic growth led tourism in developed and developing countries.

\section{Methodology}

3.1. Data. The present study explores the impact of trade openness, renewable energy consumption, foreign direct investment, and tourism on carbon emission in the world developed and developing countries over the period of 1985 to 2018. This study has employed static and dynamic long run estimators to find the dynamic and long run relationship of the study variables. All the study variables' data have been collected from the world development indicator (published by World Bank). The study variables are renewable energy consumption taken as \% of total final energy, carbon dioxide emission (metric tons per capita), trade openness, foreign direct investment (net inflows as a percent of GDP), international tourism receipt, and GDP per capita (annual growth percent). Moreover, control variables are used in the static and dynamic models that are urban population, national expenditure, and labor force.

3.2. Econometric Techniques. The current study uses OLS, fixed effect, and system GMM models to investigate the 
impact of trade openness, renewable energy consumption, foreign direct investment, and tourism on carbon dioxide emission in developing and developed countries. Further, the study also examines the long run association between the variables where FMOLS (fully modified ordinary least square) and DOLS (dynamic ordinary least square) models have been employed to explore the long run relationship of variables. The system GMM model is used because it is the most efficient estimator as OLS and fixed effect models are not efficient and may lead to several econometric problems while we have used these static models to compare the findings of this study with previous studies' results which have found different results. System GMM model has been considered by different researchers and states that two-step GMM estimator is the most efficient estimator [55]. The present study finally focuses on system GMM model to investigate the dynamic impact of trade openness, renewable energy consumption, foreign direct investment, and tourism on carbon dioxide emission in developing and developed countries. The empirical model can be illustrated as follows:

$$
\begin{aligned}
\mathrm{CO}_{\mathrm{it}}= & a_{0}+a_{1} \mathrm{CO}_{\mathrm{it}-1}+a_{2} \mathrm{RE}_{\mathrm{it}}+a_{3} \mathrm{FDI}_{\mathrm{it}}+a_{4} \mathrm{TOUR}_{\mathrm{it}} \\
& +a_{5} \mathrm{TO}_{\mathrm{it}}+a_{6} X_{\mathrm{it}}+\varepsilon_{\mathrm{it}},
\end{aligned}
$$

where $\mathrm{CO}$ represents carbon dioxide, RE shows renewable energy consumption, FDI is foreign direct investment which is calculated as the net inflows as a percent of GDP, TOUR is used to represent tourism, $\mathrm{TO}$ is trade openness, and $\mathrm{CO}_{\text {it-1 }}$ is the first lag of left hand variables used as explanatory variables in equation which enumerate the preceding year influence on current year, where $\mathrm{X}_{\mathrm{it}}$ represent control variables of the study that hypothetically affects our left hand side variable. The control variables of the study are urban population, economic growth, national expenditure, and labor force. The subscripts in the equation indicate $(i=1 \ldots$ $\mathrm{N})$ and $(t=1985 . .2018)$ index country and time, respectively.

Moreover, for the long run estimation of the study variables, the order of each variable has been tested by using different set of panel unit root tests both in first differences and in level over the period of 1885 to 2018 . These tests have been employed to confirm the nonstationary panel data series. These tests include [56], Pearson and Shin, and $[57,58]$, among which, LLC's, Breitung's, and Hadri's tests are tested which are based on the assumption of common unit root process that the coefficients of autocorrelation of the tested variables of cross sections are identical. After checking the stationary of the variables by using panel unit root tests, we will examine the cointegration within the panel. The method in [59] has been employed to investigate the presence of cointegration among the study variables. In this method, there are seven tests proposed. The first set of tests includes panel v-statistics, panel rho-statistics, panel $\mathrm{PP}$, and panel ADF statistics where authors have assumed the common autoregressive coefficients within the dimension. The second group of tests is composed of group rhostatistics, group PP-statistics, and group ADF-statistics tested between dimension and individual autoregressive coefficients assumed. All the studies employed test of panel cointegration is tested with deterministic trends and intercept. The null hypothesis of the cointegration is that there is no cointegration. The alternative hypothesis is that there exists cointegration among the study variables. The long run equilibrium deviation from the long run is represented by the residuals $\varepsilon i t$. The no cointegration null hypothesis $(\rho \mathbf{i}=1)$ has been tested through the unit root tests mentioned above. Thirdly, after checking the panel unit root and integration which allow us for long run estimation therefore it is required to look at the panel cointegration. For the long run estimation of structural coefficients, the study employed long run estimation (fully modified ordinary least square) and (dynamic ordinary least square) models where these models are better than simple OLS model because the OLS model is biased and therefore the distribution depends on annoyance factors within the perspective of panel estimation. Therefore, to eliminate the estimator bias, the proposed method of [59] is used for the cointegration of variables by employing the FMOLS model. It includes nonparametric procedure in FMOL model for serial correlation and endogeneity issues correction.

The second estimator DOLS mentioned above is additionally implemented which is additionally used for the panel data examination and is usually recommended by Kao and Chiang [54] and Mark and Sul [60]. For the aim of accomplishing our study objectives, the study estimates the regression where the $\mathrm{CO} 2$ is employed as a variable while the independent variables are renewable energy consumption, foreign direct investment, international trade, and per capita gross domestic product. The generalized form of output equation has been set to examine the association between the variables as illustrated as follows:

$$
\begin{aligned}
\mathrm{CO}_{\mathrm{it}}= & a_{0}+a_{1} \mathrm{RE}_{\mathrm{it}}+a_{2} \mathrm{FDI}_{\mathrm{it}}+a_{3} \mathrm{TOUR}_{\mathrm{it}}+a_{4} \mathrm{IT}_{\mathrm{it}} \\
& +a_{5} \mathrm{GDPPC}_{\mathrm{it}}+\varepsilon_{i t},
\end{aligned}
$$

where $\mathrm{CO}$ is used to represent carbon dioxide in equation, $\mathrm{RE}$ represents renewable energy consumption, FDI is foreign direct investment, TOUR represents international tourism, IT is trade openness, and GDPPC is per capita gross domestic product while $\varepsilon_{i t}$ is the term.

\section{Results and Discussions}

4.1. Test of Panel Unit Root and Cointegration. Table 1 represents the results of panel unit root test both in $1^{\text {st }}$ different and in level for the study variables. These tests are Levin et al. [56], Breitung [57], Pearson and Shin, and Hadri [58], among which LLC, Breitung, and Hadri's tests are common single process assumptions. All unit root tests reject the null hypothesis of specifying unit roots for all variables carbon dioxide (CO2), foreign direct investment (FDI), and renewable energy (RE), and tourism (TOUR). All the findings in the table are statistically significant at $1 \%$ significance level which further allow us for the fact that panel cointegration tests can be performed.

After using the panel unit root test to confirm the normality of the variables, this study explored the cointegration within the panel. The Pedroni [59] method was used 
TABle 1: Panel unit root tests.

\begin{tabular}{lcccccccc}
\hline \multirow{2}{*}{ Variables } & \multicolumn{2}{c}{ LLC } & \multicolumn{2}{c}{ Pearson } & \multicolumn{2}{c}{ Breitung } & \multicolumn{2}{c}{ Hadri } \\
& Level & \multicolumn{1}{c}{$1^{\text {st }}$ diff } & Level & $1^{\text {st }}$ diff & Level & $1^{\text {st }}$ diff & Level & $1^{\text {st }}$ diff \\
\hline CO2 & $0.21(0.000)^{\mathrm{a}}$ & $-21.80(000)^{\mathrm{b}}$ & $2.67(0.000)^{\mathrm{a}}$ & $-24.34(0.000)^{\mathrm{b}}$ & $9.07(1.000)$ & $-28.723(0.000)^{\mathrm{b}}$ & $30.84(0.000)^{\mathrm{a}}$ & $-5.744(0.000)^{\mathrm{b}}$ \\
FDI & $-6.67(0.000)^{\mathrm{a}}$ & $-95.55(0.000)^{\mathrm{b}}$ & $-8.21(0.000)^{\mathrm{a}}$ & $-40.61(0.000)^{\mathrm{b}}$ & $-9.95(0.000)^{\mathrm{a}}$ & $-23.88(0.000)^{\mathrm{b}}$ & $13.41(0.000)^{\mathrm{a}}$ & $5.55(0.000)^{\mathrm{b}}$ \\
RE & $-2.65(0.004)^{\mathrm{a}}$ & $-15.51(0.000)^{\mathrm{b}}$ & $-0.07(0.46)$ & $-18.69(0.000)^{\mathrm{b}}$ & $3.39(0.99)$ & $-8.65(0.000)^{\mathrm{b}}$ & $23.23(0.000)^{\mathrm{a}}$ & $10.77(0.000)^{\mathrm{b}}$ \\
TOUR & $-0.48(0.313)^{\mathrm{b}}$ & $-10.47(0.000)^{\mathrm{b}}$ & $2.92(0.99)$ & $-13.07(0.000)^{\mathrm{b}}$ & $5.45(1.000)$ & $-1.35(0.000)^{\mathrm{b}}$ & $23.29(0.000)^{\mathrm{a}}$ & $25.03(0.000)^{\mathrm{b}}$ \\
TO & $-2.98(0.0001)^{\mathrm{a}}$ & $-20.75(0.000)^{\mathrm{b}}$ & $-3.86(0.000)^{\mathrm{a}}$ & $-27.29(0.000)^{\mathrm{b}}$ & $-2.36(0.009)^{\mathrm{a}}$ & $-19.89(0.000)^{\mathrm{b}}$ & $18.89(0.000)^{\mathrm{a}}$ & $12.79(0.000)^{\mathrm{b}}$ \\
GDPPC & $-22.50(0.000)^{\mathrm{a}}$ & $-30.13(0.000)^{\mathrm{b}}$ & $-21.75(0.000)^{\mathrm{a}}$ & $-51.83(0.000)^{\mathrm{b}}$ & $-16.84(0.000)^{\mathrm{a}}$ & $-32.36(0.000)^{\mathrm{b}}$ & $16.07(0.000)^{\mathrm{a}}$ & $30.66(0.000)^{\mathrm{b}}$ \\
\hline
\end{tabular}

a and $b$ in the table denote the rejection of the null hypothesis at level and first differences, respectively.

to study the existence of cointegrations between variables. In this method, 7 tests are proposed. The first set of tests includes panel $v$ statistics, panel rho-statistics, panel PP, and panel ADF statistics that assume typical automatic regression coefficients within the dimension. The second group of tests consisted of group rho-statistics, PP group statistics, and ADF group statistics, tested between the dimension and each autoregressive coefficient. The tests used in all panel cointegration studies have decisive trends and intercepts. All panel cointegration test results accepted different assumptions, rejecting $1 \%$ of the original hypothesis without cointegration. Table 2 shows the panel cointegration test results for developing countries and developed countries from 1985 to 2019. All data sequences are cointegrated in either direction. Additional results confirm a long-term association between the study variables.

4.2. The Results of FMOLS and DOLS Models. Tables 3 reports the estimated results of all the study variables for both developing and developed countries by using two types of panel cointegration long run estimation techniques (FMOLS and DOLS). The estimation results in Table 3 show that all estimated coefficients are statistically significant. In case of developing countries, long run results of FMOLS highlight that FDI and renewable energy consumption increase $\mathrm{CO} 2$ emissions. This result is similar to [62] who also indicate that FDI increases $\mathrm{CO} 2$ emissions in Kuwait. Results regarding renewable energy consumption in FMOLS model of the current study are in line with the findings of [63] and by [64] study on Tunisia where [65] have also found that increase in renewable energy consumption increases carbon emission.

Results of our findings regarding tourism are negatively associated with carbon emission in developing countries. Authors in [66] have found similar results where they state that tourism decreases carbon emission in Central and South American countries. Our findings indicate that increase in tourism decreases $\mathrm{CO} 2$ emissions which can be linked to green tourism hypothesis because there have been contribution to the country by visiting efficient proportion of tourists which bring rich biodiversity and cleanliness as well as wild beauty. Tourism supports the country revenue and thus takes countries towards the reduction of pollution in the countries. The current study findings regarding tourism are in line with the study findings of [8] and [67]. Similarly, our findings indicate that increase in economic growth of developing countries decreases carbon emission in developing countries which are similar to the findings of [64] who illustrate that increase in economic growth decreases carbon emission in Tunisia. The results can be due to the efforts made by developing countries in abatement technologies, energy efficiency, and renewable energy use during recent decades. Likewise, our findings of trade openness show that trade openness decreases carbon emission in developing countries which can explain that more goods are imported or merchandises are exporting and need more transport and fossil energy to consume which increase carbon emission.

Similarly, the results of DOLS model indicate that FDI, tourism, and trade openness are the major drivers for carbon emission in developing countries while renewable energy consumption and economic growth significantly decrease carbon emission in developing countries. This result is reinforced by the study of [62] showing that FDI increases $\mathrm{CO} 2$ emissions in Kuwait, opposite to the findings of Zhu et al. [46]. Regarding the results of DOLS of the current study on renewable energy consumption, a $1 \%$ increase in renewable energy consumption reduces $\mathrm{CO} 2$ emissions by $0.8 \%$ which can be due to substitutability of renewable energy and fossil when increasing the use of renewable energy in place of former energy. Our results are further reinforced by the findings of $[64,68]$. Economic growth in our study indicates that it reduces carbon emission in developing countries which are in line with the results of [64] who illustrate that increase in economic growth decreases carbon emission in Tunisia. According to the study of DOLS model on tourism, an increase in tourism has been shown to increase carbon emission, which is similar to the study of [69] for Turkey and [8] on the OECD.

The results of FMOLS and DOLS in developed countries are shown in Table 3 and the long-term estimation of FMOLS and DOLS are mostly similar. FDI and tourism are the main causes of increasing carbon emissions in developed countries and renewable energy consumption and economic growth significantly reduce carbon emission. According to FMOLS and DOLS results for renewable energy consumption, a $1 \%$ increase in renewable energy consumption in FMOLS and DOLS models reduces $\mathrm{CO} 2$ emissions by 0.15 and $1.50 \%$, which can be caused by not using previous energy sources. The findings are in line with the results of Ben Jebli and Ben Youssef (2015, export model) and Ben Jebli et al. [68]. By using the FMOLS model, it has also been found that increasing the consumption of renewable energy will reduce carbon emissions. Similarly, both FMOLS and DOLS 
TABLe 2: Panel cointegration test results of developing and developed countries.

Developing countries

TABue 2: Panel cointegration test results of developing and developed countries.

\begin{tabular}{|c|c|c|c|c|}
\hline & \multicolumn{4}{|c|}{ Weighted } \\
\hline & Statistics & Prob. & Statistics & Prob. \\
\hline \multicolumn{5}{|l|}{ Alternative hypothesis: common AR coefs. (within-dimension) } \\
\hline Panel v-statistics & 5.622966 & $0.00^{* * *}$ & 3.120623 & $0.00^{* * *}$ \\
\hline Panel rho-statistics & -3.464537 & $0.00^{* * *}$ & -4.067958 & $0.00^{* * *}$ \\
\hline Panel PP-statistics & -9.767712 & $0.00^{* * *}$ & -11.73912 & $0.00^{* * *}$ \\
\hline Panel ADF-statistics & -9.865377 & $0.00^{* * *}$ & -11.94858 & $0.00^{* * *}$ \\
\hline Alternative hypothesis: individual AR coefs. (between-dimensions) & Statistics & Prob. & & \\
\hline Group rho-statistics & -0.654365 & $0.00^{* * *}$ & & \\
\hline Group PP-statistics & -16.94975 & $0.00^{* * *}$ & & \\
\hline Group ADF-statistics & -17.05732 & $0.00^{* * *}$ & & \\
\hline \multicolumn{5}{|l|}{ Developed countries } \\
\hline \multicolumn{5}{|l|}{ Alternative hypothesis: common AR coefs. (within-dimension) } \\
\hline Panel v-statistics & -0.306902 & $0.00^{* * *}$ & -0.912880 & $0.00^{* * *}$ \\
\hline Panel rho-statistics & -1.704506 & $0.00^{* * *}$ & -2.685396 & $0.00^{* * *}$ \\
\hline Panel PP-statistics & -3.675541 & $0.00^{* * *}$ & -6.971720 & $0.00^{* * *}$ \\
\hline Panel ADF-statistics & -3.278634 & $0.00^{* * *}$ & -3.920991 & $0.00^{* * *}$ \\
\hline \multicolumn{5}{|l|}{ Alternative hypothesis: individual AR coefs. (between-dimensions) } \\
\hline Group rho-statistics & -1.483837 & $0.00^{* * *}$ & & \\
\hline Group PP-statistics & -9.421885 & $0.00^{* * *}$ & & \\
\hline Group ADF-statistics & -4.441478 & $0.00^{* * *}$ & & \\
\hline
\end{tabular}

$* * *$ shows significance at the $1 \%$ level.

TABLE 3: Long run estimation of FMOLS and DOLS models.

\begin{tabular}{|c|c|c|c|c|c|c|}
\hline \multirow{2}{*}{ Variables } & \multicolumn{3}{|c|}{ FMOLS } & \multicolumn{3}{|c|}{ DOLS } \\
\hline & Coefficient & $t$-statistics & Pvalues & Coefficient & t-statistics & Prob. \\
\hline \multicolumn{7}{|c|}{ Developing countries } \\
\hline FDI & 12.4 & 4782771. & $0.000^{* * *}$ & 0.114 & 16.895 & $0.0000 .000 * * *$ \\
\hline $\mathrm{RE}$ & 48.399 & 51169.38 & $0.000^{* * *}$ & -0.143 & -8.143 & $0.000^{* * *}$ \\
\hline TOUR & -89.516 & -1346963 & $0.000^{* * *}$ & 2.511 & 25.332 & $0.000^{* * *}$ \\
\hline GDPPC & -25.7 & -19566673 & $0.000^{* * *}$ & -0.006 & -5.909 & $0.000^{* * *}$ \\
\hline TO & -16.36 & -2833926. & $0.000^{* * *}$ & 0.238 & 7.765 & $0.000^{* * *}$ \\
\hline \multicolumn{7}{|c|}{ Developed countries } \\
\hline FDI & 0.0043 & 3.193817 & $0.001^{* * *}$ & 0.005 & 3.842 & $0.000^{* * *}$ \\
\hline $\mathrm{RE}$ & -0.1533 & -2.770659 & $0.001^{* * *}$ & -0.067 & -1.503 & $0.001^{* *}$ \\
\hline TOUR & 1.061 & 4.512785 & $0.000^{* * *}$ & 7.811 & 3.924 & $0.000^{* * *}$ \\
\hline GDPPC & -0.014 & -3.684852 & $0.000^{* * *}$ & -0.047 & -7.743 & $0.000^{* * *}$ \\
\hline TO & -0.563 & -3.990995 & $0.000^{* * *}$ & -0.010 & -13.446 & $0.000^{* * *}$ \\
\hline
\end{tabular}

*** represents significance level at 1 percent.

models indicate that the increase in tourism will increase carbon emissions. The findings are similar to those of [8, 69] and Katircioglu [70], Dogan [71], and Jebli and Youssef [64] while they are contrary to the results of Lee and Brahmasrene [67] and Katircioglu [8]. Our results indicate that economic growth in developed countries is negatively correlated with carbon emissions, which is similar to the study by Ben and Youssef [64]. He also found that Tunisia's economic growth has reduced carbon emissions. Similarly, our findings indicate that open trade reduces carbon emissions in developed countries and these results contradict the findings of [66].

4.3. Results of OLS, Fixed Effect, and System GMM. Tables 4 and 5 give the results of OLS, fixed effect, and GMM estimators regarding the impact of renewable energy consumption, foreign direct investment, tourism, and trade openness on carbon emission in developing and developed countries, respectively.

4.3.1. Results for Developing Countries. Model 1, model 2, and model 3 represent OLS, FE, and system GMM models, respectively, in the table. The results of system GMM for developing countries show that the lag dependent variable is statistically significant which confirms the applicability of the model. Similarly, in the given table, Sargan test, AR1 and AR2 $p$ values also indicate the applicability of the model.

The estimated coefficient of renewable energy consumption is statistically significant and the relationship with carbon emission is negative, which indicates that renewable energy consumption negatively affects carbon emission. More specifically, the results of the OLS model show that if 
TABLE 4: The impact of renewable energy consumption, FDI, tourism, and trade openness on carbon emission in developing countries.

\begin{tabular}{|c|c|c|c|}
\hline Dep. Variable CO2 emission & Model 1 & Model 2 & Model 3 \\
\hline Renewable energy consumption & $\begin{array}{c}-0.441 * * * \\
\quad(0.011)\end{array}$ & $\begin{array}{c}-0.449^{* * *} * \\
\quad(0.022)\end{array}$ & $\begin{array}{c}-0.461^{* * *} \\
(0.003)\end{array}$ \\
\hline Foreign direct investment & $\begin{array}{l}-0.002 \\
(0.010)\end{array}$ & $\begin{array}{c}0.009^{* *} \\
(0.004)\end{array}$ & $\begin{array}{c}-0.034^{* * *} \\
(0.002)\end{array}$ \\
\hline Tourism & $\begin{array}{c}-0.000 * * * \\
(0.000)\end{array}$ & $\begin{array}{c}0.064^{* * *} \\
(0.008)\end{array}$ & $\begin{array}{c}0.054^{* * *} \\
(0.003)\end{array}$ \\
\hline Trade openness & $\begin{array}{c}0.433 * * * \\
(0.030)\end{array}$ & $\begin{array}{c}0.138^{* * *} * \\
(0.024)\end{array}$ & $\begin{array}{c}0.346^{* * *} * \\
(0.010)\end{array}$ \\
\hline L.GDP per capita & $\begin{array}{l}-0.001 \\
(0.002)\end{array}$ & $\begin{array}{c}-0.003^{* * *} \\
(0.000)\end{array}$ & $\begin{array}{c}0.058^{* * *} \\
(0.003)\end{array}$ \\
\hline Urban population & $\begin{array}{c}0.322 * * * \\
(0.019)\end{array}$ & $\begin{array}{c}-1.030^{* *} \\
(4.960)\end{array}$ & $\begin{array}{c}0.296^{* * *} \\
(0.006)\end{array}$ \\
\hline National expenditure & $\begin{array}{c}0.802 * * * \\
(0.018)\end{array}$ & $\begin{array}{c}0.432 * * * \\
(0.022)\end{array}$ & $\begin{array}{c}0.764^{* * *} \\
(0.007)\end{array}$ \\
\hline Labor force & $\begin{array}{c}2.190 * * * \\
\quad(1.741)\end{array}$ & $\begin{array}{c}3.320 * * * \\
(1.220)\end{array}$ & $\begin{array}{c}2.360^{* * *} \\
(6.011)\end{array}$ \\
\hline $\mathrm{Co} 2_{\text {it }-1}$ & & & $\begin{array}{c}-1.150 * * * \\
(7.080)\end{array}$ \\
\hline Constant & $-15.28 * * *$ & $-1.393 * * *$ & $\begin{array}{c}-14.70^{* * *} * \\
(0.097)\end{array}$ \\
\hline Observations & 1,709 & 1,709 & 1,380 \\
\hline Number of IDs & & 112 & 111 \\
\hline $\mathrm{R}$ squared & 0.953 & 0.664 & \\
\hline $\operatorname{AR}(1)$ & & & $-2.48(0.001)$ \\
\hline $\operatorname{AR}(2)$ & & & $-0.85(0.395)$ \\
\hline Sargan test & & & $17454.7(0.101)$ \\
\hline
\end{tabular}

$* * *$ and $* *$ show significance level at 1 and 2 percent, respectively.

TABLE 5: The impact of renewable energy consumption, FDI, tourism, and trade openness on carbon emission in developed countries.

\begin{tabular}{|c|c|c|c|}
\hline Dep. Variable CO2 emission & Model 1 & Model 2 & Model 3 \\
\hline Renewable energy consumption & $\begin{array}{c}-0.325^{* * *} \\
(0.0214)\end{array}$ & $\begin{array}{c}-0.127^{* * *} \\
(0.039)\end{array}$ & $\begin{array}{c}-0.204^{* * *} \\
(0.015)\end{array}$ \\
\hline Foreign direct investment & $\begin{array}{c}0.051^{* * *} * \\
(0.018)\end{array}$ & $\begin{array}{c}0.024 * * \\
(0.009)\end{array}$ & $\begin{array}{c}0.022 * * \\
(0.009)\end{array}$ \\
\hline Tourism & $\begin{array}{c}0.000 * * * \\
(0.000)\end{array}$ & $\begin{array}{c}0.080 * * * \\
(0.028)\end{array}$ & $\begin{array}{c}-0.144^{* * *} \\
(0.020)\end{array}$ \\
\hline Trade openness & $\begin{array}{c}-0.694^{* * *} \\
(0.048)\end{array}$ & $\begin{array}{c}-0.312^{* * *} \\
(0.119)\end{array}$ & $\begin{array}{c}-0.235^{* * *} \\
(0.048)\end{array}$ \\
\hline L.GDP per capita & $\begin{array}{l}-0.006 \\
(0.005)\end{array}$ & $\begin{array}{c}-0.012^{* * * *} \\
(0.003)\end{array}$ & $\begin{array}{c}0.0224 * * \\
(0.010)\end{array}$ \\
\hline Urban population & $\begin{array}{c}0.511^{* * *} \\
(0.078)\end{array}$ & $\begin{array}{c}3.850 \\
(2.660)\end{array}$ & $\begin{array}{c}0.461^{* * *} \\
(0.033)\end{array}$ \\
\hline National expenditure & $\begin{array}{c}0.385^{* * *} \\
(0.066)\end{array}$ & $\begin{array}{c}0.922^{* * *} * \\
(0.230)\end{array}$ & $\begin{array}{c}0.585^{* * *} \\
(0.033)\end{array}$ \\
\hline Labor force & $\begin{array}{l}-5.941 \\
(3.130)\end{array}$ & $\begin{array}{c}5.860 \\
(3.980)\end{array}$ & $\begin{array}{c}-5.660^{* * *} \\
(5.810)\end{array}$ \\
\hline $\mathrm{Co} 2_{\text {it-1 }}$ & & & $\begin{array}{c}3.190^{* * *} \\
(3.150)\end{array}$ \\
\hline Constant & $\begin{array}{c}-3.287^{* * *} \\
(0.774)\end{array}$ & $\begin{array}{c}6.212 * * * \\
(1.446)\end{array}$ & $\begin{array}{c}-6.926^{* * *} \\
(0.478)\end{array}$ \\
\hline Observations & 173 & 173 & 141 \\
\hline Number of IDs & & 9 & 9 \\
\hline $\mathrm{R}$ squared & 0.982 & 0.416 & \\
\hline $\operatorname{AR}(1)$ & & & $-5.01(0.000)$ \\
\hline $\operatorname{AR}(2)$ & & & $-0.57(0.566)$ \\
\hline Sargan test & & & $836.88(0.101)$ \\
\hline
\end{tabular}

*** and $* *$ show significance level at 1 and 2 percent, respectively. 
renewable energy consumption increases by one percent, carbon emission in developing countries will decrease by 0.44 . The fixed effect model also shows that if renewable energy consumption increases by $1 \%$, carbon emissions in developing countries will decrease by 0.44 . Similarly, the system GMM results also show that if renewable energy consumption increases by $1 \%$, the carbon emissions of developing countries will reduce by $0.46 \%$. The result may be due to the substitution between renewable energy consumption and fossils, which can be achieved by reducing the former's energy consumption when increasing the volume or renewable energy consumption. Our results are in line with the findings of $[66,68,72]$ where they also found that the increase in renewable energy consumption significantly reduced carbon emissions. However, the current research results are contrary to the findings of $[63,64]$.

The estimated coefficient of foreign direct investment is also significant both in fixed effect and in system GMM while the sign for fixed effect is positive and our main focus of the study is system GMM which indicates that FDI inflow has decreasing effect on carbon emission and if there is a percent increase in FDI, this will reduce carbon emission by 0.03 percent in the developing countries. This result is in line with the findings of $[46,63,64,72,73]$ who also show that the inflow of foreign direct investment reduces carbon emission.

Similarly, the estimated coefficient of tourism in mostly in all models has a statistically significant impact on carbon emission and the relationship with carbon dioxide emissions is positive. For instance, results of system GMM for developing countries indicate that if a percentage in tourism increases, the carbon emissions of developing countries will increase by $0.05 \%$. These results are consistent with the findings of $[8,69]$ in Turkey OECD countries [74] and [64]. Tunisia provides that increasing tourism will increase carbon emission. The coefficient of trade openness for developing countries is very highly significant while the relationship is positive with carbon emission which indicates that trade openness increases carbon emission of developing countries. More specifically, the results of the OLS and fixed effect models indicate that if trade openness increases by a certain percentage, the carbon emissions of developing countries will increase by $0.43 \%$ and $0.13 \%$, respectively. Similarly, the system GMM results also show that if trade openness increases by $1 \%$, the carbon emission of developing countries will increase by $0.34 \%$. Authors in $[74,75]$ further confirmed this result and they also found that the opening of trade significantly affects carbon emission. Similarly, with the exception of the OLS model, the GDP per capita in all models has a high statistical significance. The relationship of per capita GDP and carbon emissions is positive in system GMM which indicates that the GDP per capita increases carbon emission. Similarly, mostly in all models, the estimated coefficients of the urban population, labor force, and national expenditure are positive and significant which indicates an increasing impact of these variables on carbon emission in developing countries.

4.3.2. Results for Developed Countries. The lag dependent variable of carbon emission is statistically significant which confirms the applicability of the model. Similarly, in the given table, Sargan test, AR1 and AR2 $p$ values also indicate the applicability of the model. Likewise, the impact of renewable energy consumption, FDI, tourism, and trade openness on carbon emission in developing countries is given in Table 4 where the estimated coefficient of renewable energy consumption is highly statistically significant at 1 percent significance level and its association with carbon emission is negative which indicates that renewable energy consumption reduces carbon emission in developed countries. More specifically, the results of system GMM indicate that if there is a percent increase in renewable energy consumption, this will reduce carbon emission by 0.46 in developed countries. The results further suggest that renewable energy consumption in the study countries is beneficial for environmental quality and the use of renewable energy from renewable sources has increased enough and the use of energy from fossil fuels has been reduced at enough level. That can be reason of negative influence of renewable energy consumption on carbon emission in the sample countries. These results are similar to those of $[66,72]$.

Similarly, the estimated coefficient of foreign direct investment on the carbon emissions for developed countries is also very highly significant while the relationship with carbon dioxide emissions is positive in the OLS, fixed effects, and system GMM which indicates that the increase in foreign direct investment increases carbon emission in developed countries. For instance, the results of system GMM indicate that if there is a percent increase in FDI inflow, this will increase carbon emission by 0.022 percent in developed countries. This result may be due to the fact that a large number of foreign direct investment projects use effective amounts of energy or the level of renewable energy production projects is low. The current findings are similar to the results of [62], who also found that FDI increased carbon emissions.

Similarly, the estimated coefficient of tourism in OLS and FE models is statistically significant at $1 \%$ significance and the relationship with carbon dioxide emissions is positive which shows that tourism increases carbon emission while our main focus of the study is on system GMM model which shows that tourism negatively affects carbon emission. For instance, the result of system GMM indicates that if there is a percent increase in tourism, this will decrease carbon emission by 0.144 percent in developed countries. This result can be explained by the need for important tourist entry, abundant biodiversity, and the need to increase tourist entry to earn income and drive these countries to reduce pollution in developed countries. The results are similar to those found by $[8,67]$, which also pointed out that increasing tourism will reduce carbon emissions.

Similarly, the coefficient of trade openness for developed countries is highly significant while the relationship is negative with carbon emission indicating that trade openness negatively affects carbon emission in the sample countries. More specifically, the results of the OLS and fixed effect models indicate that if trade openness increases by a certain percentage, the carbon emission in developed 
countries will decrease by 0.23 percent. Authors in $[74,75]$ further confirmed this result and they also found that the opening of trade significantly reduced carbon emissions. The estimated coefficient of per capita GDP in system GMM is significant and positive indicating that increase in GDP per capita increases carbon emissions while it is not true for OLS and FE models. Likewise, other control variables which are urban population and national expenditure are highly significant and positive mostly in all models which indicate that increase in these two factors increases carbon emission in developed countries while labor force is negatively associated with carbon emission only in developed countries.

\section{Conclusion and Policy Implication}

This study investigates the impact of renewable energy consumption, trade openness, foreign direct investment, and tourism on carbon emission in world developed and developing countries for the period of 1985 to 2018. The study uses OLS, fixed effect, and system GMM models to investigate the dynamic association between variables. Further, the study also examines the long run association between the variables where FMOLS (fully modified ordinary least square) and DOLS (dynamic ordinary least square) models have been employed to explore the long run relationship among the study variables.

The results of system GMM indicate that renewable energy consumption negatively and significantly affect carbon emission in both developed and developing countries which means that increase in renewable energy consumption enhances the quality of environment in both samples. The use of renewable energy from renewable sources has been increased which is beneficial for the quality of environment in both developed and developing countries instead of the use of former's energy and energy from fossil fuels. Similarly, foreign direct investment negatively and significantly affects carbon emission in developing countries while it is positive significantly in developed countries which indicates that foreign direct investment decreases carbon emission in developing counties and increases carbon emission in developing countries. The nonsimilar results of FDI in developing and developed countries might be the reason of different level of FDI inflow and rules for foreign investors as well as environmental regulations differences. Likewise, tourism has positive impact on carbon emission in case of developing countries which illustrates that increase in international tourism increases emission in these countries. The result is negatively significant for developed countries illustrating that it reduces emission in developed countries. The findings regarding tourism for both samples indicate that international tourism rules and levels are different compared to developed countries and therefore this has positive impact on carbon emission. The coefficient of trade openness for developing countries is also positive on carbon emission which shows that trade openness increases emission in the countries while it is negative for developed countries indicating that trade openness reduces emission in developed countries. The difference in results for developed and developing countries is due to the weak formulation of trade openness and trade or the level of trade in developing countries. Dogan and Turkekul [15] have also found that openness to trade increases emission in some of their sample countries while it has no effect on some countries. They show that it may be due to the composition and techniques of trade activities in different countries.

Moreover, particular attention has been given to the long run association of these variables with carbon emission. By using panel cointegration, FMOLS and DOLS models, the results indicate that there exists long run association of the study variables with carbon emission in both developed and developing countries. In case of developing countries, long run results of FMOLS highlight that FDI and renewable energy consumption increase $\mathrm{CO} 2$ emissions. Moreover, tourism is associated negatively with carbon emission in developing countries which illustrates that increase in international tourism reduces emission which may be linked to the hypothesis of green tourism because it seems that tourism contributes to the countries' biodiversity and cleanliness. Likewise, economic growth and trade openness also decrease carbon emission in developing countries. Similarly, the DOLS model for developing countries indicates that FDI, tourism, and international trade have an increasing impact on carbon emission in developing countries while renewable energy consumption and economic growth significantly decrease carbon emission in developing countries. In case of developed countries, FMOLS and DOLS long run estimation indicates that FDI and tourism are the main drivers of increasing carbon emission in developed countries while renewable energy consumption economic growth and trade openness significantly reduce carbon emission in developed countries.

There is a rapid increase in economic integration among countries which has created a debate for this field with regard to economic growth and environmental quality. Governments of countries try to increase economic growth through FDI and trade openness and at the same time have to focus on environmental sustainability prior to businesses or international trade decisions. Priority is given to enhance economic activities which give maximum economic and social benefits and at the same time to protect or less affect the quality of environment. Similarly, the use of energy plays a very important role in economic activities expansion and enhances economic growth while the use of energy from fossil fuels degrades the quality of environment of a country. Recently, most of the countries are trying to promote the use of renewable energy which can be obtained from renewable energy sources that might help to increase economic growth and to enhance the quality of environment. However, the renewable energy use has not yet reached the desired level especially in developing and low-income countries.

Our findings have considerable suggestions specifically for developing countries to enhance the renewable energy consumption and develop sources for renewable energy which can be a major driver to enhance the quality of environment. Moreover, countries are advised to have special polices when attracting FDI to improve infrastructure which can also contribute to tourism while keeping in view environmental policies. Policies should be adopted to enhance 
international tourism and investments related to tourism which can be a good contribution to global warming. Additionally, these projects related administrative fee should be reduced such as technical, marketing, and business related fee which can support tourism activities. Policies regarding tourism sector could be a good strategy to expand the use of renewable energy and encouraging renewable energy could enhance tourists' activities to the countries. Trade openness should also be promoted in both countries as it plays an important role in economic growth; however, strong polices should be adopted to avoid environmental degradation. Our study is limited to the study variables, developed and developing countries. Further studies should consider different regions/countries and include other factors such as institutional quality, education, and innovation to investigate the determinants of carbon emission.

\section{Data Availability}

The data used in this paper is available on the World Bank database world development indicator (https://databank. worldbank.org/source/world-development-indicators) and are available upon request by sending an e-mail to the corresponding author.

\section{Conflicts of Interest}

The authors declare that there are no conflicts of interest.

\section{Acknowledgments}

This research was supported by the major project funded by the Research Base of Humanities and Social Sciences of the Ministry of Education of China "Comparative Study of Chinese and Foreign Special Economic Zones" (Project no. 16JJD790042).

\section{References}

[1] M. J. Ferrantino, "International trade, environmental quality and public policy," World Economy, vol. 20, no. 1, pp. 43-72, 1997.

[2] W. Antweiler, B. R. Copeland, and M. S. Taylor, "Is free trade good for the environment?" American Economic Review, vol. 91, no. 4, pp. 877-908, 2001.

[3] M. S. B. Aïssa, M. B. Jebli, and S. B. Youssef, "Output, renewable energy consumption and trade in Africa," Energy Policy, vol. 66, pp. 11-18, 2014.

[4] K. Menyah and Y. Wolde-Rufael, "Energy consumption, pollutant emissions and economic growth in South Africa," Energy Economics, vol. 32, no. 6, pp. 1374-1382, 2010.

[5] S. Shafiei and R. A. Salim, "Non-renewable and renewable energy consumption and CO2 emissions in OECD countries: a comparative analysis," Energy Policy, vol. 66, pp. 547-556, 2014.

[6] H. Khan, I. Khan, and T. T. Binh, "The heterogeneity of renewable energy consumption, carbon emission and financial development in the globe: a panel quantile regression approach," Energy Reports, vol. 6, pp. 859-867, 2020.

[7] H. Khan, I. Khan, L. T. Kim Oanh, and Z. Lin, "The dynamic interrelationship of environmental factors and foreign direct investment: dynamic panel data analysis and new evidence from the globe," Mathematical Problems in Engineering, vol. 2020, Article ID 2812489, 12 pages, 2020.

[8] S. T. Katircioglu, "International tourism, energy consumption, and environmental pollution: the case of Turkey," Renewable and Sustainable Energy Reviews, vol. 36, pp. 180-187, 2014.

[9] X. Wang, H. Lin, J. Hong, and Z. Mi, "Spatial effects of foreign direct investment on carbon emissions: evidence from China's provincial panel data," in Proceedings of the Energy Transitions in the 21st Century, 37th USAEE/IAEE North American Conference, Denver, CO, USA, November 2019.

[10] Y. Huang, X. Chen, H. Zhu, C. Huang, and Z. Tian, "The heterogeneous effects of FDI and foreign trade on $\mathrm{CO} 2$ emissions: evidence from China," Mathematical Problems in Engineering, vol. 2019, Article ID 9612492, 14 pages, 2019.

[11] L. Zhu, Y. Hao, Z. N. Lu, H. Wu, and Q. Ran, "Do economic activities cause air pollution? Evidence from China's major cities," Sustainable Cities and Society, vol. 49, Article ID 101593, 2019.

[12] A. C. Marques and R. Caetano, "The impact of foreign direct investment on emission reduction targets: evidence from high- and middle-income countries," Structural Change and Economic Dynamics, vol. 55, pp. 107-118, 2020.

[13] C. T. Tugcu, I. Ozturk, and A. Aslan, "Renewable and nonrenewable energy consumption and economic growth relationship revisited: evidence from G7 countries," Energy Economics, vol. 34, no. 6, pp. 1942-1950, 2012.

[14] U. Al-mulali, H. G. Fereidouni, and J. Y. M. Lee, "Electricity consumption from renewable and non-renewable sources and economic growth: evidence from Latin American countries," Renewable and Sustainable Energy Reviews, vol. 30, pp. 290298, 2014.

[15] E. Dogan and B. Turkekul, "CO2 emissions, real output, energy consumption, trade, urbanization and financial development: testing the EKC hypothesis for the USA," Environmental Science and Pollution Research, vol. 23, no. 2, pp. 1203-1213, 2016.

[16] J. Bernard and S. K. Mandal, "The impact of trade openness on environmental quality: an empirical analysis of emerging and developing economies," WIT Transactions on Ecology and the Environment, vol. 203, pp. 195-208, 2016.

[17] T. Y. Ling, R. Ab-Rahim, and K. A. Mohd-Kamal, "Trade openness and environmental degradation in asean-5 countries," International Journal of Academic Research in Business and Social Sciences, vol. 10, no. 2, 2020.

[18] O. Gasimli, S. K. N. Haq, F. Gamage, P. S. K. Shihadeh, M. Rajapakshe, and fnm Shafiq, "Energy, trade, urbanization and environmental degradation nexus in Sri Lanka: bounds testing approach," Energies, vol. 12, no. 9, p. 1655, 2019.

[19] M. Mahrinasari, M. Haseeb, and J. Ammar, "Is trade liberalization a hazard to sustainable environment?: fresh insight from ASEAN countries," Polish Journal of Management Studies, vol. 19, 2019.

[20] T. H. Le, Y. Chang, and D. Park, "Trade openness and environmental quality: International evidence," Energy Policy, vol. 92, pp. 45-55, 2016.

[21] Q. Zhang, X. Jiang, D. Tong et al., “Transboundary health impacts of transported global air pollution and international trade," Nature, vol. 543, no. 7647, pp. 705-709, 2017.

[22] H. M. Ertugrul, M. Cetin, F. Seker, and E. Dogan, "The impact of trade openness on global carbon dioxide emissions: evidence from the top ten emitters among developing countries," Ecological Indicators, vol. 67, pp. 543-555, 2016. 
[23] B. Njindan Iyke and S. Y. Ho, "Trade openness and carbon emissions: evidence from central and Eastern European Countries," Review of Economics, vol. 70, no. 1, pp. 41-67, 2017.

[24] Z. Fang, B. Huang, and Z. Yang, Trade Openness and the Environmental Kuznets Curve: Evidence from Cities in the People's Republic of China, Wiley, Hoboken, NJ, USA, 2018.

[25] A. Omri, "CO2 emissions, energy consumption and economic growth nexus in MENA countries: Evidence from simultaneous equations models," Energy Economics, vol. 40, pp. 657-664, 2013.

[26] C. Yu, D. Nataliia, S. J. Yoo, and Y. S. Hwang, "Does trade openness convey a positive impact for the environmental quality? Evidence from a panel of CIS countries," Eurasian Geography and Economics, vol. 60, no. 3, pp. 333-356, 2019.

[27] H. P. Sun, G. Tariq, M. Haris, and M. Mohsin, "Evaluating the environmental effects of economic openness: evidence from SAARC countries," Environmental Science and Pollution Research, vol. 26, no. 24, pp. 24542-24551, 2019.

[28] A. T. Nguyen, "The relationship between economic growth, energy consumption and carbon dioxide emissions: evidence from central Asia," Eurasian Journal of Business and Economics, vol. 12, no. 24, pp. 1-15, 2019.

[29] O. A. Osobajo, A. Otitoju, M. A. Otitoju, and A. Oke, "The impact of energy consumption and economic growth on carbon dioxide emissions," Sustainability, vol. 12, no. 19, p. $7965,2020$.

[30] P. Sadorsky, "Renewable energy consumption, $\mathrm{CO} 2$ emissions and oil prices in the G7 countries," Energy Economics, vol. 31, no. 3, pp. 456-462, 2009.

[31] O. Ocal and A. Aslan, "Renewable energy consumptioneconomic growth nexus in Turkey," Renewable and Sustainable Energy Reviews, vol. 28, pp. 494-499, 2013.

[32] N. Apergis and J. E. Payne, "Renewable energy, output, CO2 emissions, and fossil fuel prices in Central America: evidence from a nonlinear panel smooth transition vector error correction model," Energy Economics, vol. 42, pp. 226-232, 2014.

[33] J. M. Lee, K. H. Chen, and C. H. Cho, "The relationship between $\mathrm{CO} 2$ emissions and financial development: evidence from OECD countries," The Singapore Economic Review, vol. 60, no. 5, Article ID 1550117, 2015.

[34] J. A. Odugbesan and H. Rjoub, "Relationship among economic growth, energy consumption, $\mathrm{CO} 2$ emission, and urbanization: evidence from MINT countries," Sage Open, vol. 10, no. 2, 2020.

[35] J. A. Odugbesan and H. Rjoub, "Evaluating HIV/Aids prevalence and sustainable development in sub-Saharan Africa: the role of health expenditure," African Health Sciences, vol. 20, no. 2, pp. 568-578, 2020.

[36] H. M. A. Siddique, "Impact of financial development and energy consumption on $\mathrm{CO} 2$ emissions: evidence from Pakistan," Bulletin of Business and Economics, vol. 6, no. 2, pp. 68-73, 2017.

[37] X. Ma and Q. Fu, "The influence of financial development on energy consumption: worldwide evidence," International Journal of Environmental Research and Public Health, vol. 17, no. 4, p. 1428, 2020.

[38] J. Jian, X. Fan, P. He, H. Xiong, and H. Shen, "The effects of energy consumption, economic growth and financial development on CO2 emissions in China: A VECM approach," Sustainability, vol. 11, no. 18, p. 4850, 2019.

[39] C. Jiang and X. Ma, "The impact of financial development on carbon emissions: a global perspective," Sustainability, vol. 11, no. 19, p. 5241, 2019.
[40] T. Adamu, I. Haq, and M. Shafiq, "Analyzing the impact of energy, export variety, and FDI on environmental degradation in the context of environmental kuznets curve hypothesis: a case study of India," Energies, vol. 12, no. 6, p. 1076, 2019.

[41] L. Zhu, Y. Hao, Z. N. Lu, H. Wu, and Q. Ran, "Do economic activities cause air pollution? Evidence from China's major cities," Sustainable Cities and Society, vol. 49, Article ID 101593, 2019.

[42] Z. Li, H. Dong, Z. Huang, and P. Failler, "Impact of foreign direct investment on environmental performance," Sustainability, vol. 11, no. 13, p. 3538, 2019.

[43] A. H. To, D. T.-T. Ha, H. M. Nguyen, and D. H. Vo, "The impact of foreign direct investment on environment degradation: evidence from emerging markets in Asia," International Journal of Environmental Research and Public Health, vol. 16, no. 9, p. 1636, 2019.

[44] G. Y. Zakarya, B. Mostefa, S. M. Abbes, and G. M. Seghir, "Factors affecting $\mathrm{CO} 2$ emissions in the BRICS countries: a panel data analysis," Procedia Economics and Finance, vol. 26, pp. 114-125, 2015.

[45] C. M. Huynh and H. H. Hoang, "Foreign direct investment and air pollution in Asian countries: does institutional quality matter?" Applied Economics Letters, vol. 26, no. 17, pp. 1388-1392, 2019.

[46] H. Zhu, L. Duan, Y. Guo, and K. Yu, "The effects of FDI, economic growth and energy consumption on carbon emissions in ASEAN-5: evidence from panel quantile regression," Economic Modelling, vol. 58, pp. 237-248, 2016.

[47] L. Chen, B. Thapa, and W. Yan, "The relationship between tourism, carbon dioxide emissions, and economic growth in the Yangtze River Delta, China," Sustainability, vol. 10, no. 7, p. $2118,2018$.

[48] C. T. Tugcu and M. Topcu, "Total, renewable and non-renewable energy consumption and economic growth: revisiting the issue with an asymmetric point of view," Energy, vol. 152, pp. 64-74, 2018.

[49] J. Zhang and Y. Zhang, "Tourism, economic growth, energy consumption, and CO2 emissions in China," Tourism Economics, vol. 26, pp. 353-527, 2020.

[50] S. A. Solarin, "Tourist arrivals and macroeconomic determinants of $\mathrm{CO} 2$ emissions in Malaysia," Anatolia, vol. 25, no. 2, pp. 228-241, 2014.

[51] S. Fethi and E. Senyucel, "The role of tourism development on $\mathrm{CO} 2$ emission reduction in an extended version of the environmental kuznets curve: evidence from top 50 tourist destination countries," Environment, Development and Sustainability, vol. 23, no. 2, pp. 1499-1524, 2021.

[52] P. Hanpattanakit, L. Pimonsree, A. Jamnongchob, and A. Boonpoke, "CO2 emission and reduction of tourist transportation at kok mak island, Thailand," Chemical Engineering Transactions, vol. 63, pp. 37-42, 2018.

[53] S. J. Abul, E. Satrovic, and A. Muslija, "The link between energy consumption and economic growth in Gulf Cooperation Council countries," International Journal of Energy Economics and Policy, vol. 9, no. 5, pp. 38-45, 2019.

[54] K. Zaman, M. Shahbaz, N. Loganathan, and S. A. Raza, "Tourism development, energy consumption and Environmental Kuznets Curve: Trivariate analysis in the panel of developed and developing countries," Tourism Management, vol. 54, pp. 275-283, 2016.

[55] S. H. Law and W. N. W. Azman-Saini, "Institutional quality, governance, and financial development," Economics of Governance, vol. 13, no. 3, pp. 217-236, 2012. 
[56] A. Levin, C.-F. Lin, and C.-S. James Chu, "Unit root tests in panel data: asymptotic and finite-sample properties," Journal of Econometrics, vol. 108, no. 1, pp. 1-24, 2002.

[57] J. Breitung, "The local power of some unit root tests for panel data," in Nonstationary Panels, Panel Cointegration, and Dynamic Panels, pp. 161-177, Emerald Group Publishing Limited, Bingley, UK, 2001.

[58] K. Hadri, "Testing for stationarity in heterogeneous panel data," The Econometrics Journal, vol. 3, no. 2, pp. 148-161, 2000.

[59] P. Pedroni, "Panel cointegration: asymptotic and finite sample properties of pooled time series tests with an application to the PPP hypothesis," Econometric Theory, vol. 20, no. 3, pp. 597-625, 2004.

[60] C. Kao and M. H. Chiang, "On the estimation and inference of a cointegrated regression in panel data," in Nonstationary Panels, Panel Cointegration, and Dynamic Panels, Emerald Group Publishing Limited, Bingley, UK, 2001.

[61] N. C. Mark and D. Sul, "Cointegration vector estimation by panel DOLS and long-run money demand," Oxford Bulletin of Economics and Statistics, vol. 65, no. 5, pp. 655-680, 2003.

[62] M. Salahuddin, K. Alam, I. Ozturk, and K. Sohag, "The effects of electricity consumption, economic growth, financial development and foreign direct investment on $\mathrm{CO} 2$ emissions in Kuwait," Renewable and Sustainable Energy Reviews, vol. 81, pp. 2002-2010, 2018.

[63] N. Apergis and J. E. Payne, "Renewable energy consumption and growth in Eurasia," Energy Economics, vol. 32, no. 6, pp. 1392-1397, 2010.

[64] M. B. Jebli and S. B. Youssef, "The environmental Kuznets curve, economic growth, renewable and non-renewable energy, and trade in Tunisia," Renewable and Sustainable Energy Reviews, vol. 47, pp. 173-185, 2015.

[65] M. Simionescu, Y. Bilan, E. Krajňáková, D. Streimikiene, and S. Gędek, "Renewable energy in the electricity sector and GDP per capita in the European Union," Energies, vol. 12, no. 13, p. 2520, 2019.

[66] M. B. Jebli, S. B. Youssef, and N. Apergis, "The dynamic linkage between renewable energy, tourism, $\mathrm{CO} 2$ emissions, economic growth, foreign direct investment, and trade," Latin American Economic Review, vol. 28, no. 1, p. 2, 2019.

[67] J. W. Lee and T. Brahmasrene, "Investigating the influence of tourism on economic growth and carbon emissions: evidence from panel analysis of the European Union," Tourism Management, vol. 38, pp. 69-76, 2013.

[68] M. B. Jebli, S. B. Youssef, and I. Ozturk, "Testing environmental Kuznets curve hypothesis: the role of renewable and non-renewable energy consumption and trade in OECD countries," Ecological Indicators, vol. 60, pp. 824-831, 2016.

[69] G. De Vita, S. Katircioglu, L. Altinay, S. Fethi, and M. Mercan, "Revisiting the environmental Kuznets curve hypothesis in a tourism development context," Environmental Science and Pollution Research, vol. 22, no. 21, pp. 16652-16663, 2015.

[70] S. T. Katircioglu, M. Feridun, and C. Kilinc, "Estimating tourism-induced energy consumption and $\mathrm{CO} 2$ emissions: the case of Cyprus," Renewable and Sustainable Energy Reviews, vol. 29, pp. 634-640, 2014.

[71] E. Dogan, "CO2 Emissions, Real GDP, Renewable energy and tourism: evidence from panel of the most-visited countries," Statistika: Statistics and Economy Journal, vol. 97, no. 3, pp. 63-76, 2017.

[72] M. Mert and G. Bölük, "Do foreign direct investment and renewable energy consumption affect the $\mathrm{CO} 2$ emissions? New evidence from a panel ARDL approach to Kyoto Annex countries," Environmental Science and Pollution Research, vol. 23, no. 21, pp. 21669-21681, 2016.

[73] C. Atici, "Carbon emissions, trade liberalization, and the Japan-ASEAN interaction: a group-wise examination," Journal of the Japanese and International Economies, vol. 26, no. 1, pp. 167-178, 2012.

[74] E. Dogan, F. Seker, and S. Bulbul, "Investigating the impacts of energy consumption, real GDP, tourism and trade on CO2emissions by accounting for cross-sectional dependence: a panel study of OECD countries," Current Issues in Tourism, vol. 20, no. 16, pp. 1701-1719, 2017.

[75] K. Jayanthakumaran, R. Verma, and Y. Liu, "CO2 emissions, energy consumption, trade and income: a comparative analysis of China and India," Energy Policy, vol. 42, pp. 450-460, 2012. 